\title{
First study of Cryptosporidium spp. occurrence in eared doves (Zenaida auriculata)
}

\author{
Primeiro estudo de ocorrência de Cryptosporidium spp. em pomba-de-bando (Zenaida auriculata) \\ Mércia de Seixas ${ }^{1}$; Alessandra Taroda ${ }^{1}$; Sérgio Tosi Cardim ${ }^{1}$; João Pedro Sasse ${ }^{1}$; Thais Agostinho Martins ${ }^{1}$; \\ Felippe Danyel Cardoso Martins ${ }^{1}$; Ana Flávia Minutti ${ }^{1}$; Odilon Vidotto ${ }^{1}$; Luiz Daniel de Barros ${ }^{1}$; Joáo Luis Garcia ${ }^{1 *}$ (D) \\ ${ }^{1}$ Departamento de Medicina Veterinária Preventiva, Laboratório de Protozoologia Animal, Universidade Estadual de Londrina - \\ UEL, Londrina, PR, Brasil
}

Received November 12, 2018

Accepted February 27, 2019

\begin{abstract}
Cryptosporidium is a protozoan parasite with a wide range of hosts, including humans. However, only a few Cryptosporidium species have been described in birds (C. meleagridis, C. baileyi, C. galli and C. avium). The aim of this study was to investigate the occurrence of Cryptosporidium spp. in feces of eared doves (Zenaida auriculata), followed by molecular characterization of the parasite. A total of 196 animals of both sexes were trap-captured; the animals were culled and the intestinal contents were collected for DNA extraction. After extraction, a nested-PCR (nPCR), which amplifies a fragment of the $18 \mathrm{~S}$ rRNA gene of Cryptosporidium spp., was performed. The amplicons obtained were purified and sequenced. PCR analysis revealed that 30 animals $(15.3 \%)$ were positive for Cryptosporidium spp. There was no significant sex-dependent enrichment of Cryptosporidium occurrence ( $\mathrm{p}>0.05)$. Only 15 out of the 30 positive samples were successfully sequenced and their species determined, of which, $13(86.7 \%)$ and $2(13.3 \%)$ were $C$. meleagridis and C. galli, respectively. Herein, we present for the first time a molecular characterization of Cryptosporidium from feces of eared doves ( $Z$. auriculata) and propose that these birds are a potential source of $C$. meleagridis infection in humans.
\end{abstract}

Keywords: Pigeons, epidemiology, cryptosporidiosis, PCR.

\section{Resumo}

Cryptosporidium é um protozoário com uma grande variedade de hospedeiros, incluindo os seres humanos. No entanto, poucas espécies têm sido descritas em aves (Cryptosporidium meleagridis, C. baileyi, C. galli e C. avium). O objetivo do presente estudo foi investigar a ocorrência de Cryptosporidium spp. em fezes de pombas-de-bando (Zenaida auriculata), e realizar a caracterizaçáo molecular dos isolados. Um total de 196 animais de ambos os sexos foram capturados, eutanasiados e o conteúdo intestinal recolhido para extração de DNA. Após a extração, realizou-se uma nested-PCR (nPCR), que amplifica um fragmento do gene 18S rRNA do Cryptosporidium spp.. Os fragmentos obtidos foram purificados e encaminhados para sequenciamento. Os resultados da n-PCR revelaram 30 animais (15.3\%) positivos para Cryptosporidium spp.. Quanto ao sexo dos animais não foram observadas diferenças estatísticas significativas $(\mathrm{p}>0.05)$. Somente 15 de 30 amostras positivas foram sequenciadas com sucesso e as espécies determinadas, das quais, 13 (86.7\%) e $2(13.3 \%)$ foram C. meleagridis e C. galli, respectivamente. Esse é o primeiro estudo com caracterizaçáo molecular de Cryptosporidium de fezes de pombas-de-bando (Z. auriculata), e propóe serem esses animais potenciais fonte de infecção de C. meleagridis para humanos.

Palavras-chave: Pombos, epidemiologia, criptosporidiose, PCR.

\section{Introduction}

Cryptosporidium is a protozoa parasite able to infect mammals, reptiles, birds, and fishes (MONIS \& THOMPSON, 2003). The first report of Cryptosporidium in birds was made by Tyzzer (1929),

*Corresponding author: João Luis Garcia. Departamento de Medicina Veterinária Preventiva, Laboratório de Protozoologia Animal, Universidade Estadual de Londrina - UEL, Rodovia Celso Garcia Cid, Pr 445 km 380, CEP 86057-970, Londrina, PR, Brasil. e-mail: jlgarcia@uel.br who found the parasite in the intestinal epithelium of young hens. To date, 38 species of Cryptosporidium have been described worldwide (FENG et al., 2018), however only four species are able to infect birds: C. baileyi, C. galli, C. meleagridis and $C$. avium (NAKAMURA \& MEIRELES, 2015; HOLUBOVÁ et al., 2016). C. meleagridis has zoonotic potential and causes diarrhea in children and immunodeficient individuals (MBAE et al., 2015). C. meleagridis is responsible for approximately $10 \%$ of the 
human cryptosporidiosis cases reported in Peru and Thailand (WANG et al., 2014).

Zenaida auriculata (Columbiforme) is endemic from Antilles to Tierra del Fuego, including Brazil. This dove is popularly known as the eared dove and is found in fields, farms, and urban areas (CÂNDIDO et al., 2008), where it can cause damage and potentially transmit pathogens (SHIBATTA et al., 2009).

There are no studies of Cryptosporidium spp. in eared doves; therefore, we aimed to study the occurrence of Cryptosporidium spp. from feces of eared doves and to determine the involved species.

\section{Material and Methods}

\section{Sampling and local of capture}

A total of 196 eared doves from both sexes were captured in gauze-traps in the urban region of Londrina city, northern of Paraná state, located between $23^{\circ} 08^{\prime} 47^{\prime \prime}$ and $23^{\circ} 55^{\prime} 46^{\prime \prime}$ south and between $50^{\circ} 52^{\prime} 23^{\prime \prime}$ and $51^{\circ} 19^{\prime} 11^{\prime \prime}$ west. Sampling was done by area and convenience. The present study was approved by the Brazilian Institute of Environment (IBAMA - SISBIO n. 16428-1) and by the Ethics Committee of Animal Experimentation from the State University of Londrina (n. 70/2008).

\section{Sample collection}

After being trap-captured, the birds were euthanized and the gastrointestinal tracts were removed. Intestinal contents were collected in a petri plate and divided into aliquots in microtubes to be frozen at $-20^{\circ} \mathrm{C}$ and subsequently used for DNA extraction.

\section{DNA extraction}

For DNA extraction, fecal samples were frozen and thawed at $-80{ }^{\circ} \mathrm{C}$ and $30^{\circ} \mathrm{C}$, respectively, three times. After this, $1 \mathrm{~mL}$ Tris-EDTA (TE) was added for each $50 \mu \mathrm{L}$ of fecal samples, then this solution was mixed and centrifuged at $4,000 \times \mathrm{g}$ for 15 minutes. The supernatant was poured off, and the pellet was used for the extraction with the Nucleospin Tissue ${ }^{\circledast}$ kit (Macherey-Nagel, Germany), following the manufacturer's instructions. Negative (ultrapure water) and positive ( $C$. parvum oocysts) controls were included in all DNA extraction procedures.

\section{Nested PCR}

DNA amplification was performed in triplicate by nPCR targeting the $18 \mathrm{~S}$ rRNA region using primers previously described for Cryptosporidium (XIAO et al., 1999, 2000). In the first reaction, the primers used were Fw1 (5'-TTCTAGAGCTAATACATGCG-3') and Rv2 (5'-CCCATTTCCTTCGAAACAGGA-3'). The second reaction was performed using the primers Fw3 (5'-GGAAGGGTTGTATTTATTAGATAAAG-3') and Rv4 (5'-AAGGAGTAAGGAACAACCTCCA-3'). Reactions were performed using $1 \times$ PCR buffer, $2.5 \mathrm{mM}$ of $\mathrm{MgCl}_{2}, 0.2 \mu \mathrm{M}$ of DNTP, $0.2 \mu \mathrm{M}$ of each primer, 1.2 U of Platinum Taq (Invitrogen ${ }^{\circ}$ ),
$2.5 \mu \mathrm{l}$ of DNA and sterilized ultrapure water (total volume of $25 \mu \mathrm{L}$ ). In both reactions, the same cycling conditions were used: $95^{\circ} \mathrm{C}$ for 5 minutes, followed by 34 cycles of $94^{\circ} \mathrm{C}$ for 45 seconds, $55^{\circ} \mathrm{C}$ for 45 seconds and $72^{\circ} \mathrm{C}$ for 1 minute, with a final extension of $72^{\circ} \mathrm{C}$ for 5 minutes. DNA from C. parvum and ultrapure water were included in all PCR reactions as positive and negative controls respectively. Products from the second amplification were visualized under ultraviolet light after electrophoresis on a $1.5 \%$ agarose gel stained with SYBR ${ }^{\circ}$ Safe (Invitrogen, USA) and photodocumented by LPix Imagem ST Software (Loccus Biotecnologia).

\section{Sequencing and phylogenetic tree}

Amplicons from the nPCR were purified using the Purelink Quick Gel Extraction Kit (Invitrogen, USA). After purification, they were submitted for sequencing with BigDye Terminator v3.1 Cycle Sequencing Kit (Applied Biosystems, USA), at the ABI3730xl Genetic Analyzer (Applied Biosystems, USA). The data obtained from sequencing allowed the comparison between complementary amplicons from the same samples, generating a consensus, which was compared by Blast to the sequences deposited at GenBank for determination of species. Bioedit Sequence Alignment Editor v7.2.5 Software was used to align the sequences, including a reference sample of Eimeria tenella (DQ640011.1) as the outgroup.

The consensus sequence was predicted by MEGA6 Software (TAMURA et al., 2013), where the neighbor-joining tree was built with the sequences obtained herein and others deposited at GenBank, using Kimura 2-parameter distance matrix (KIMURA, 1980). Statistical analysis was performed using bootstrapping with 1,000 repetitions.

\section{Statistical analysis}

Sex dependence of Cryptosporidium occurrence by Chi-square $\left(\mathrm{X}^{2}\right)$ test with a confidence interval of $95 \%$, using the OpenEpi 3.03a software; $\mathrm{p} \leq 0.05$ was considered as significant.

\section{Results}

Thirty fecal samples (15.3\%) out of 196 were identified as positives using nPCR and submitted for sequencing. Male and female animals had 10.8\% (10/92) and 19.2\% (20/104) of positive samples ( $p>0.05$ ), respectively. Because of low DNA quantity, just 15 out of 30 samples had a good sequencing, thirteen (87\%) of them matched C. meleagridis and two (13\%) C. galli. The phylogenetic tree (Figure 1) showed two branches: one grouping the 13 samples with genetic similarity of $99 \%$ with the standard C. meleagridis (AF329186.1, AF180339.1, EU284595.1, KJ851537.1 and JX141294.1), and the second one grouping the two samples with 99\% of similarity with C. galli (GU734647.1). The nucleotide sequences generated from the positive samples were deposited in GenBank under accession numbers MF405448 to MF405462. 


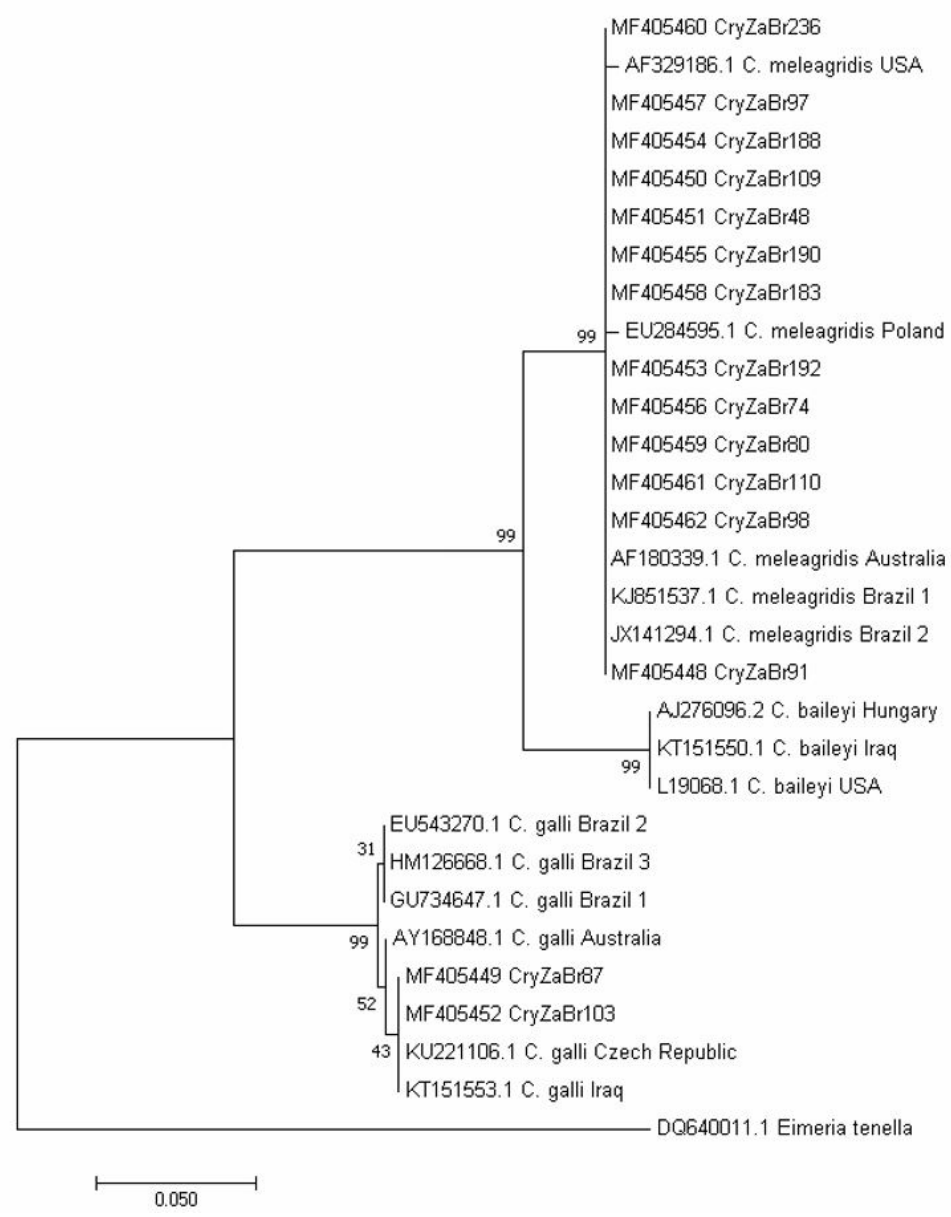

Figure 1. Phylogenetic tree of the $18 \mathrm{~S}$ rRNA gene sequences of Cryptosporidium detected in feces from eared doves Zenaida auriculata. CryZaBr\# are isolates from our study.

\section{Discussion}

To the best of our knowledge, this study shows, for the first time, the molecular prevalence and characterization of Cryptosporidium spp. in fecal samples from eared doves. We observed $15.3 \%$ positive samples, of which, $87 \%$ were identified as C. meleagridis and $13 \%$ as C. galli. The first molecular characterization of Cryptosporidium in Columba livia (Columbiformes) was reported by Oliveira et al. (2017). Contrary to our results, they observed a lower prevalence (7\%) of Cryptosporidium and reported C. parvum as the predominant parasite species.

Cryptosporidium meleagridis infection affects mainly children and immunodeficient individuals (CHAPPELL et al., 2011; CAMA et al., 2007). The data obtained show the potential of eared doves to act as a source of $C$. meleagridis infection in humans. This protozoan parasite has also been reported in pigeons, chickens, and ducks from China (WANG et al., 2010; LI et al., 2015). The eared doves feed on the ground, mainly in farms, and can fly long distances, from where they sleep to the place they spend the day, therefore, we speculate that eared doves might be acting as vectors of cryptosporidiosis and involved in transmitting the infection from one region to another (BUCHER \& BOCCO, 2009).

\section{Conclusions}

Our study is the first to report Cryptosporidium infection in the eared dove $Z$. auriculata, along with genetic characterization of $C$. meleagridis and $C$. galli. These results suggest that this bird species could be a source of $C$. meleagridis infection in humans.

\section{Acknowledgements}

This study received financial support from the Coordenação de Aperfeiçoamento de Pessoal de Nível Superior (CAPES, AUX-PE-PARASITOLOGIA-1345/2011, 10259/12-0). J.L. Garcia and O. Vidotto are recipients of CNPq fellowships.

\section{References}

Bucher EH, Bocco PJ. Reassessing the importance of granivorous pigeons as massive, long-distance seed dispersers. Ecology 2009; 90(8): 2321-2327. http://dx.doi.org/10.1890/08-2077.1. PMid:19739393.

Cama VA, Ross JM, Crawford S, Kawai V, Chavez-Valdez R, Vargas $\mathrm{D}$, et al. Differences in clinical manifestations among Cryptosporidium 
species and subtypes in HIV-infected persons. J Infect Dis 2007; 196(5): 684-691. http://dx.doi.org/10.1086/519842. PMid:17674309.

Cândido JF Jr, Snak C, Castaldelli APA, Brocardo CR, Model KJ. Dieta de avoantes (Zenaida auriculata Des Murs, 1847) atropeladas na BR-277 entre Cascavel e Foz do Iguaçu-PR e implicaçôes para seu manejo. Rev Bras Biocienc 2008; 6(Suppl 1): 68-69.

Chappell CL, Okhuysen PC, Langer-Curry RC, Akiyoshi DE, Widmer G, Tzipori S. Cryptosporidium meleagridis: infectivity in healthy adult volunteers. Am J Trop Med Hyg 2011; 85(2): 238-242. http://dx.doi. org/10.4269/ajtmh.2011.10-0664. PMid:21813841.

Feng Y, Ryan UM, Xiao L. Genetic diversity and population structure of Cryptosporidium. Trends Parasitol 2018; 34(11): 997-1011. http://dx.doi. org/10.1016/j.pt.2018.07.009. PMid:30108020.

Holubová N, Sak B, Horčičková M, Hlásková L, Květoňová D, Menchaca $\mathrm{S}$, et al. Cryptosporidium avium n. sp. (Apicomplexa: cryptosporidiidae) in birds. Parasitol Res 2016; 115(6): 2243-2251. http://dx.doi.org/10.1007/ s00436-016-4967-8. PMid:26905074.

Kimura M. A simple method for estimating evolutionary rate of base substitutions through comparative studies of nucleotide sequences. J Mol Evol 1980; 16(2): 111-120. http://dx.doi.org/10.1007/BF01731581. PMid:7463489.

Li J, Lin X, Zhang L, Qi N, Liao S, Lv M, et al. Molecular characterization of Cryptosporidium spp. in domestic pigeons (Columba livia domestica) in Guangdong Province, Southern China. Parasitol Res 2015; 114(6): $2237-$ 2241. http://dx.doi.org/10.1007/s00436-015-4415-1. PMid:25773186.

Mbae C, Mulinge E, Waruru A, Ngugi B, Wainaina J, Kariuki S. Genetic diversity of Cryptosporidium in children in an urban informal settlement of Nairobi, Kenya. PLoS One 2015; 10(12): e0142055. http://dx.doi. org/10.1371/journal.pone.0142055. PMid:26691531.

Monis PT, Thompson RC. Cryptosporidium and Giardia-zoonoses: fact or fiction? Infect Genet Evol 2003; 3(4): 233-244. http://dx.doi. org/10.1016/j.meegid.2003.08.003. PMid:14636685.
Nakamura AA, Meireles MV. Cryptosporidium infections in birds - a review. Rev Bras Parasitol Vet 2015; 24(3): 253-267. http://dx.doi.org/10.1590/ S1984-29612015063. PMid:26444057.

Oliveira BCM, Ferrari ED, Cruz Panegossi MF, Nakamura AA, Corbucci FS, Nagata WB, et al. First description of Cryptosporidium parvum in carrier pigeons (Columba livia). Vet Parasitol 2017; 243: 148-150. http:// dx.doi.org/10.1016/j.vetpar.2017.06.023. PMid:28807284.

Shibatta OA, Galves W, Carmo WPD, Lima IP, Lopes EV, Machado RA. A fauna de vertebrados do campus da Universidade Estadual de Londrina, regiāo norte do estado do Paraná, Brasil. Semin Cienc Biol Saude 2009; 30(1): 3-26. http://dx.doi.org/10.5433/1679-0367.2009v30n1p3.

Tamura K, Stecher G, Peterson D, Filipski A, Kumar S. MEGA6: Molecular evolutionary genetics analysis version 6.0. Mol Biol Evol 2013; 30(12): 2725-2729. http://dx.doi.org/10.1093/molbev/mst197. PMid:24132122.

Tyzzer EE. Coccidiosis in gallinaceous birds. Am J Hyg 1929; 10(2): 269-383.

Wang R, Jian F, Sun Y, Hu Q, Zhu J, Wang F, et al. Large-scale survey of Cryptosporidium spp. in chickens and Pekin ducks (Anas platyrhynchos) in Henan, China: prevalence and molecular characterization. Avian Pathol 2010; 39(6): 447-451. http://dx.doi.org/10.1080/03079457.2010.51 8314. PMid:21154053.

Wang Y, Yang W, Cama V, Wang L, Cabrera L, Ortega Y, et al. Population genetics of Cryptosporidium meleagridis in humans and birds: evidence for cross-species transmission. Int J Parasitol 2014; 44(8): 515-521. http:// dx.doi.org/10.1016/j.ijpara.2014.03.003. PMid:24727090.

Xiao L, Alderísio K, Limor J, Royer M, Lal AA. Identification of species and sources of Cryptosporidum oocysts in storm waters with a small-subunit rRNA-based diagnostic and genotyping tool. Appl Environ Microbiol 2000; 66(12): 5492-5498. http://dx.doi.org/10.1128/AEM.66.12.54925498.2000. PMid:11097935.

Xiao L, Escalante L, Yang C, Sulaiman I, Escalante AA, Montali RJ, et al. Phylogenetic analysis of Cryptosporidium parasites based on the smallSubunit rRNA gene locus. Appl Environ Microbiol 1999; 65(4): $1578-$ 1583. PMid:10103253. 